\title{
BIOLOGY AND POPULATION STUDIES OF TWO ENDEMIC NEMATOCERAS (ORCHID) SPECIES ON SUB-ANTARCTIC MACQUARIE ISLAND
}

\author{
by M. L. Skotnicki, G. R. Copson, J. Doube, L. Gadd, J. M. Selkirk-Bell \\ and P. M. Selkirk
}

(with one text-figure, three plates and one table)

Skotnicki, M.L., Copson, G.R., Doube, J., Gadd, L., Selkirk-Bell, J.M. \& Selkirk, P.M. 2009 (11:xii): Biology and population studies of two endemic Nematoceras (orchid) species on sub-Antarctic Macquarie Island. Papers and Proceedings of the Royal Society of Tasmania 143(2): 61-71. https://doi.org/10.26749/rstpp.143.2.61 ISSN 0080-4703. Functional Ecology Group, Research School of Biology, Australian National University, Canberra, ACT 2601, Australia (MLS*); Dept of Primary Industries, Parks, Water and Environment, GPO Box 44, Hobart, Tasmania 7001, Australia (GRC); Australian Antarctic Division, Channel Highway, Kingston, Tasmania 7005, Australia (JD); Tasmanian Parks and Wildlife Service, PO Box 126, Moonah, Tasmania 7009, Australia (LG); 85 Lawson Street, Spring Gully, Victoria 3550, Australia (JMS-B); Department of Biological Sciences, Macquarie University, Sydney, NSW 2109, Australia (PMS)*Auth •r for correspondence. Email: mary.skotnicki@anu.edu.au

Two endemic orchid species, Nematoceras dienemum and N. sulcatum, are known from sub-Antarctic Macquarie Island. Several additional orchid populations on the island are reported and cleistogamy is documented in $N$. dienemum for the first time. The known population sizes, habitats and locations for both orchid species are documented here, and new information on their biology and population ecoløgy is prøvided.

Key Words: Nematoceras, Corybas, helmet orchid, Macquarie Island, sub-Antarctic.

\section{INTRODUCTION}

Two endemic species of orchids, Nematoceras dienemum (D.L. Jones) D.L. Jones, M.A. Clem. et Molloy (Brown et al. 1978, Jones 1993) and N. sulcatum M.A. Clem. et D.L. Jones (Mackenzie et al. 2005, Clements \& Jones 2006, Clements et al. 2007) are known from the northern half of sub-Antarctic Macquarie Island (fig. 1). Members of the genera Nematoceras and Corybas are amongst those referred to in Australia as "helmet orchids" but referred to in New Zealand as "spider orchids". The two Macquarie Island species have recently become known by the common names Windswept Helmet Orchid ( $N$. dienemum) (Wapstra et al. 2005) and Grooved Helmet Orchid (N. sulcatum) (Wapstra et al. 2007).

Since the discovery of $N$. dienemum in 1976 as Corybas macranthus (Brown et al. 1978), morphological, taxonomic and systematic studies have been made (Mackenzie et al. 2005, Clements \& Jones 2006, Clements et al. 2007), but the orchid populations, like many plant populations on Macquarie Island, have been poorly studied. Here we document population sizes, habitats and locations for these unique sub-Antarctic orchids, and provide new illustrations and information on their life histories and population ecology.

Approximately halfway between Tasmania and Antarctica, Macquarie Island has an area of 12785 ha (Parks and Wildlife Service 2006) (fig. 1). It is uplifted ocean floor that first emerged above sea level 600 000-700 000 years ago (Adamson et al. 1996), is the above-sea portion of the Macquarie Ridge, and has never been connected to any other land mass. All indigenous terrestrial and freshwater

FIG. 1 - Map of Macquarie Island showing known Nematoceras populations at sites numbered as in table 1. Other locations mentioned in text are shown by initials: MP Mawson Point, FC Finch Creek valley, SqL Square Lake, BL Brothers Lake, SuL Surrey Lake, JNB Jessie Niccol Basin.

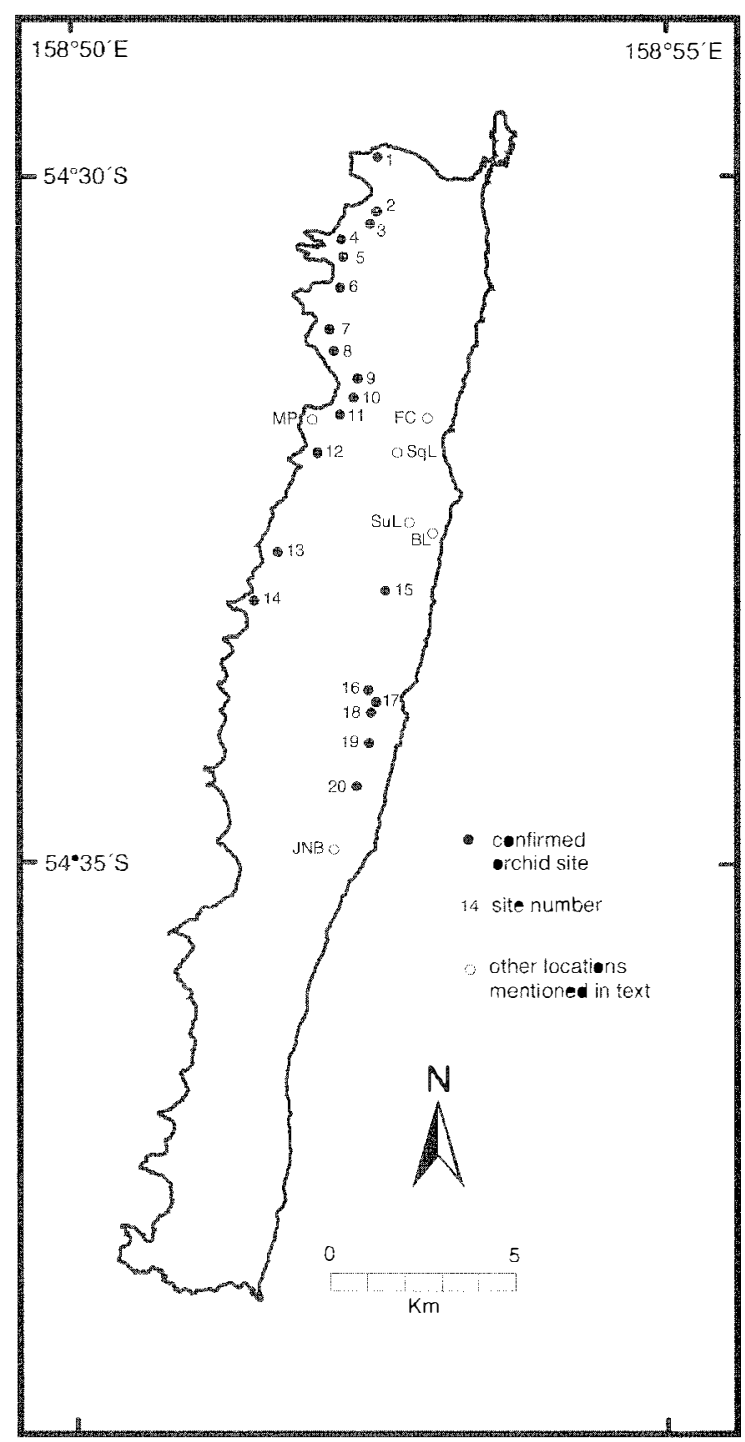


organisms have reached the island by long-distance transoceanic dispersal via ocean currents, winds or birds (Brown et al. 1978, Bergstrom \& Selkirk 1987, Muñoz et al. 2004, Dartnall et al. 2005).

The genus Nematoceras Hook.f. is endemic to New Zealand and Southern Ocean islands (Clements et al. 2007). To the south of New Zealand, one species occurs on Antipodes Island ( $\left.49^{\circ} 41^{\prime} \mathrm{S}, 178^{\circ} 48^{\prime} \mathrm{E}\right)$ and two species on the Auckland Islands $\left(50^{\circ} 29^{\prime}\right.$ to $50^{\circ} 59^{\prime} \mathrm{S}, 165^{\circ} 52^{\prime}$ to $\left.166^{\circ} 20^{\prime} \mathrm{E}\right)$. The flora of Campbell Island $\left(52^{\circ} 33^{\prime} \mathrm{S}, 169^{\circ} 09^{\prime} \mathrm{E}\right)$, includes eight species of orchid, including two species of Nematoceras (NZ Native Orchid Group 2009). The two species of Nematoceras endemic to Macquarie Island (vicinity of $54^{\circ} 30^{\prime} \mathrm{S}, 158^{\circ} 55^{\prime} \mathrm{E}$ ) are the most southerly in the genus. Although five species of orchids are known from further south, in Tierra del Fuego, South America (Moore 1983), the two species of Nematoceras endemic to Macquarie Island are of great interest, being the only orchids known from an oceanic sub-Antarctic island.

\section{MATERIALS AND METHODS}

Field studies were undertaken on Macquarie Island between 1977 and 2009. During field surveys in 1978 and 1980-81 for the Flora Atlas, orchids were recorded as "local and rare" in 14 of the island's $1 \mathrm{~km}^{2}$ grid squares (Copson 1984). Because of the vagaries of shipping access to Macquarie Island, many visits by summer scientists (MLS, JMS-B, PMS) were of limited duration or at suboptimum times of year for assessing orchid growth. Overwintering personnel (GRC, JD, LG) have been able, alongside their other tasks on the island, to extend observations into the autumn, winter and spring months.

During summer 2004 and 2009, as many of the known populations of orchids were visited as time allowed. Their extent and precise locations were recorded using hand-held Global Positioning Systems (GPS). During 2006 and 2007, thorough searches for further orchid populations were made, concentrating on locations with habitats apparently suitable for orchid growth such as very moist areas with low-growing vegetation similar to sites where orchid populations had been found. The stage of flower development was documented for each population whenever possible.

Voucher specimens for the two orchid species from Macquarie Island are lodged in the Australian National Herbarium, Canberra (CANB) and the Tasmanian Herbarium, Hobart (HO).

\section{RESULTS}

\section{Location of populations}

In summet 2004 and subsequently, GPS were used to record the extent and precise locations of known populations of orchids (fig. 1, table 1). Locations where orchids had earlier been recorded, but which could not be accessed during summers 2004-09, are also included in table 1. During 2006, 2007 and 2009, the extent and precise location of several new populations were recorded at Bauer Bay, in the Green Gorge North basin and the Red River valley (table 1). Flower development in several populations was recorded and photographed over the summer months.

Searches between late spring and early autumn failed to find further orchid populations in other parts of the island with apparently suitable habitats, including the Jessie Niccol Basin, the Sawyer Creek valley, the western and eastern edges of Red River valley, Finch Creek valley, the environs of Square Lake, the drainage line into Brothers Lake from the south, the drainage line towards Brothers Hut from the south, and the basin below Surrey Lake (fig. 1).

\section{Populations of $N$. dienemum}

The largest known population of $N$. dienemum occurs at Handspike Corner where a few plants are scattered over an area of roughly $100 \mathrm{~m} \mathrm{x} 100 \mathrm{~m}$ (fig. 1, table 1). Most plants are clustered in slightly sheltered and very wet locations in hollows in the ground, many around pool margins, between the rocky shoreline and about halfway to the base of the escarpment. Recent overgrazing by European Rabbits, Oryctolagus cuniculus (Linnaeus, 1758), on the island has completely removed the shelter previously provided by leaves of Stilbocarpa polaris (Homb. et Jacq.) Gray (pl. la, b). The orchids are still present and do not appear to be grazed by rabbits, perhaps partly because leaves now tend to remain at the bryophyte vegetation surface, rather than extending upwards.

The populations at other sites along the northwest featherbed (Half Moon Bay to Boiler Rocks, fig. 1) are much smaller. Here the populations of $N$. dienemum occur in sheltered locations at the base of the escarpment or near the base of rock stacks, most often under Stilbocarpa leaves. The population at Eagle Cave was the first to be recorded, by Nigel Brothers in 1976 .

At Bauer Bay, a well-observed population of $N$. dienemum occurs near the hut on approximately $10 \mathrm{~m} \times 10 \mathrm{~m}$ of open waterlogged ground vegetated with bryophytes and previously a few Stilbocarpa plants (now removed by rabbit overgrazing). Towards the southern end of Bauer Bay, near Gentoo Flats, an additional small orchid population was found during early 2009 (P. Bricher and J. Wasley, pers. comm.) and we confirmed this species as $N$. dienemum in March 2009.

Towards the north of Bauer Bay basin, near the track leading to Emerald Lake, a small orchid population was observed in 1979. Further south along the west coast, at each of Aurora Cave, Aurora Point near the base of the escarpment, and inland of Cormorant Point about $100 \mathrm{~m}$ west of the escarpment base, small colonies have been seen growing in the shelter of Stilbocarpa leaves. None of these populations could be located either in summer 2004 or 2006, so neither the population sizes nor species are known, although $N$. dienemum seems most likely.

At Green Gorge, several small $N$. dienemum populations are known in the mire, growing in extremely wet conditions; the largest of these sub-populations is spread over an area of probably $50 \mathrm{~m} \times 50 \mathrm{~m}$ but is difficult of access due to the extremely wet conditions.

\section{Populations of $N$. sulcatum}

Orchids were first observed in the Sawyer Creek valley in the late 1970 s (GRC), and later were described as Nematoceras sulcatum (Mackenzie et al. 2005, Clements \& Jones 2006, Clements et al. 2007) (pl.2a). One population of N. sulcatum, $1.2 \mathrm{~km}$ south of Green Gorge in the Sawyer Creek valley, on the eastern side of the valley south of the waterfall, comprises sparsely-scattered plants in an area approximately $6 \mathrm{~m} \times 3$ $\mathrm{m}$, with a few additional plants some $20 \mathrm{~m}$ further south 
Table 1

Population details for Nematoceras spp. on Macquarie Island

\begin{tabular}{|c|c|c|c|c|c|c|}
\hline $\begin{array}{l}\text { Site } \\
\text { no. }\end{array}$ & Species & $\begin{array}{l}\text { Location name } \\
\text { (year first observed) }\end{array}$ & $\begin{array}{l}\text { Latitude } \\
\text { longitude }\end{array}$ & $\begin{array}{l}\text { Area } \\
\left(\mathrm{m}^{2}\right)\end{array}$ & $\begin{array}{c}\text { Colony } \\
\text { size } \\
\text { (plants) }\end{array}$ & Notes \\
\hline 1 & N. dienemum & Handspike Corner (1980) & $\begin{array}{l}54^{\circ} 29^{\prime} 51^{\prime \prime} \mathrm{S} \\
158^{\circ} 53^{\prime} 18^{\prime \prime} \mathrm{E}\end{array}$ & 10000 & $5000+$ & $\begin{array}{l}\text { Numerous sites between rocky coast and } \\
\text { halfway to escarpment }\end{array}$ \\
\hline 2 & N. dienemum & Half Moon Bay (1977) & $\begin{array}{l}54^{\circ} 30^{\prime} 43^{\prime \prime} \mathrm{S} \\
158^{\circ} 53^{\prime} 14^{\prime \prime} \mathrm{E}\end{array}$ & $1000+$ & $500+$ & Several sites near base of escarpment \\
\hline 3 & N. dienemum & Elizabeth and Mary Point (1980) & $\begin{array}{l}54^{\circ} 30^{\prime} 50^{\prime \prime} \mathrm{S} \\
158^{\circ} 52^{\prime} 42^{\prime \prime} \mathrm{E}\end{array}$ & $\begin{array}{c}\text { Not } \\
\text { known }\end{array}$ & $\begin{array}{c}\text { Not } \\
\text { known }\end{array}$ & $\begin{array}{l}\text { Site near base of escarpment, orchids } \\
\text { locally common }\end{array}$ \\
\hline 4 & N. dienemum & Eagle Point & $\begin{array}{l}54^{\circ} 31^{\prime} 0^{\prime \prime} \mathrm{S} \\
158^{\circ} 53^{\prime} 14^{\prime \prime} \mathrm{E}\end{array}$ & $\begin{array}{c}\text { Not } \\
\text { known }\end{array}$ & $\begin{array}{c}\text { Not } \\
\text { known }\end{array}$ & $\begin{array}{l}\text { Colonies sparsely scattered over small } \\
\text { area, orchids amongst mosses }\end{array}$ \\
\hline 5 & N. dienemum & Eagle Cave (1976) & $\begin{array}{l}54^{\circ} 31^{\prime} 19^{\prime \prime} \mathrm{S} \\
158^{\circ} 52^{\prime} 8^{\prime \prime} \mathrm{E}\end{array}$ & $\begin{array}{c}\text { Not } \\
\text { known }\end{array}$ & $\begin{array}{l}\text { Not } \\
\text { known }\end{array}$ & Site of first observation of orchids 1976 \\
\hline 6 & N. dienemum & Langdon Bay (2005) & $\begin{array}{l}54^{\circ} 31^{\prime} 48^{\prime \prime} \mathrm{S} \\
158^{\circ} 52^{\prime} 21^{\prime \prime} \mathrm{E}\end{array}$ & 600 & $\begin{array}{c}\text { Not } \\
\text { known }\end{array}$ & Site near base of escarpment \\
\hline 7 & N. dienemum & Douglas Bay (1984) & $\begin{array}{l}54^{\circ} 32^{\prime} 24^{\prime \prime} \mathrm{S} \\
158^{\circ} 52^{\prime} 7^{\prime \prime} \mathrm{E}\end{array}$ & 100 & $\begin{array}{c}\text { Not } \\
\text { known }\end{array}$ & Several sites near base of escarpment \\
\hline 8 & N. dienemum & Boiler Rocks (1979) & $\begin{array}{l}54^{\circ} 32^{\prime} 42^{\prime \prime} \mathrm{S} \\
158^{\circ} 52^{\prime} 16^{\prime \prime} \mathrm{E}\end{array}$ & $20+$ & $500+$ & $\begin{array}{l}\text { Several sites between coast and base of } \\
\text { escarpment }\end{array}$ \\
\hline 9 & Nematoceras sp. & North Bauer Bay (1979) & $\begin{array}{l}54^{\circ} 32^{\prime} 56^{\prime \prime} \mathrm{S} \\
158^{\circ} 52^{\prime} 46^{\prime \prime} \mathrm{S}\end{array}$ & $\begin{array}{c}\text { Not } \\
\text { known }\end{array}$ & $\begin{array}{l}\text { Not } \\
\text { known }\end{array}$ & \\
\hline 10 & $N$. dienemum & Bauer Bay hut (1979) & $\begin{array}{l}54^{\circ} 33^{\prime} 20^{\prime \prime} \mathrm{S} \\
158^{\circ} 52^{\prime} 37^{\prime \prime} \mathrm{E}\end{array}$ & 100 & 500 & To south east of hut \\
\hline 11 & N. dienemum & Gentoo Flats (2009) & $\begin{array}{l}54^{\circ} 33^{\prime} 30^{\prime \prime} \mathrm{S} \\
158^{\circ} 52^{\prime} 24^{\prime \prime} \mathrm{S}\end{array}$ & 20 & 100 & \\
\hline 12 & Nematoceras sp. & Cormorant Point (1978) & $\begin{array}{l}54^{\circ} 34^{\prime} 10^{\prime \prime} \mathrm{S} \\
158^{\circ} 51^{\prime} 56^{\prime \prime} \mathrm{E}\end{array}$ & $\begin{array}{c}\text { Not } \\
\text { known }\end{array}$ & $\begin{array}{l}\text { Not } \\
\text { known }\end{array}$ & Site near base of escarpment \\
\hline 13 & Nematoceras sp. & South of Aurora Cave (1977) & $\begin{array}{l}54^{\circ} 35^{\prime} 34^{\prime \prime} \mathrm{S} \\
158^{\circ} 50^{\prime} 43^{\prime \prime} \mathrm{E}\end{array}$ & $\begin{array}{c}\text { Not } \\
\text { known }\end{array}$ & $\begin{array}{c}\text { Not } \\
\text { known }\end{array}$ & \\
\hline 14 & Nematoceras sp. & Aurora Point (1984) & $\begin{array}{l}54^{\circ} 37^{\prime} 18^{\prime \prime} \mathrm{S} \\
158^{\circ} 50^{\prime} 18^{\prime \prime} \mathrm{E}\end{array}$ & $\begin{array}{c}\text { Not } \\
\text { known }\end{array}$ & $\begin{array}{c}\text { Not } \\
\text { known }\end{array}$ & Orchids quite common \\
\hline 15 & N. sulcatum & Red River (2006) & $\begin{array}{l}54^{\circ} 36^{\prime} 12^{\prime \prime} \mathrm{S} \\
158^{\circ} 53^{\prime} 40^{\prime \prime} \mathrm{E}\end{array}$ & 100 & 300 & \\
\hline 16 & N. sulcatum & Green Gorge North Basin (1984) & $\begin{array}{l}54^{\circ} 37^{\prime} 37^{\prime \prime} \mathrm{S} \\
158^{\circ} 53^{\prime} 8^{\prime \prime} \mathrm{E}\end{array}$ & 2000 & $1300+$ & Two sites approx. $100 \mathrm{~m}$ apart \\
\hline 17 & $N$. dienemum & Green Gorge Mire (1980) & $\begin{array}{l}54^{\circ} 37^{\prime} 47^{\prime \prime} \mathrm{S} \\
158^{\circ} 53^{\prime} 35^{\prime \prime} \mathrm{E}\end{array}$ & 2500 & $1000+$ & In mire, west of tarn \\
\hline 18 & Nematoceras sp. & South West Green Gorge (1980) & $\begin{array}{l}54^{\circ} 38^{\prime} 3^{\prime \prime} \mathrm{S} \\
158^{\circ} 53^{\prime} 7^{\prime \prime} \mathrm{E}\end{array}$ & $\begin{array}{c}\text { Not } \\
\text { known }\end{array}$ & $\begin{array}{l}\text { Not } \\
\text { known }\end{array}$ & \\
\hline 19 & N. sulcatum & Sawyer Creek (1980) & $\begin{array}{l}54^{\circ} 38^{\prime} 25^{\prime \prime} \mathrm{S} \\
158^{\circ} 53^{\prime} 1^{\prime \prime} \mathrm{E}\end{array}$ & 40 & 1000 & \\
\hline 20 & N. sulcatum & Pyramid Peak (1980) & $\begin{array}{l}54^{\circ} 39^{\prime} 9^{\prime \prime} \mathrm{S} \\
158^{\circ} 52^{\prime} 47^{\prime \prime} \mathrm{E}\end{array}$ & 250 & $10000+$ & \\
\hline
\end{tabular}

(fig. 1, table 1). Another population, a further $2.9 \mathrm{~km}$ to the south and about $700 \mathrm{~m}$ north of Pyramid Peak, is very much larger, comprising many thousands of plants and occupying an area of some $5 \mathrm{~m} \times 50 \mathrm{~m}$. In a single square metre quadrat in December 2006, we counted over 1100 distinct orchid leaves in the site near Pyramid Peak, and there were many similarly dense areas at this location.

A thorough search of potential orchid habitats confirmed two additional adjacent populations of orchids north of Green Gorge, first observed in the 1980s (GRC) but until now, undescribed (pl. 2c). They are located very close together, and are shown as a single population at Green Gorge North (Site 16 on fig. 1, table 1) some $200 \mathrm{~m}$ to $300 \mathrm{~m}$ west of the Overland walking track, approximately $1.3 \mathrm{~km}$ northwest of Green Gorge hut. This population is not within the Green Gorge basin and mire, but is upstream and uphill to the north. It has clearly not been dispersed by water from the large and widespread population of $N$. dienernum that occurs within the Green Gorge mire.

Searches for new orchid locations also led to the discovery of a population in the Red River valley (site 15, fig.1, pl 2d), approximately $3.3 \mathrm{~km}$ north of Green Gorge, $100 \mathrm{~m}$ east of the Overland walking track. The orchids are scattered over a site some $5 \mathrm{~m} \mathrm{x} 20 \mathrm{~m}$, at approximately $100 \mathrm{~m}$ a.s.l. In early 2007 the population was estimated at several hundred plants, including many that were flowering.

The orchids in the two new Green Gorge North and Red River valley populations appear morphologically very similar to $N$. sulcatum from sites in the Sawyer Creek valley, south of Green Gorge, although the Green Gorge North orchids have somewhat more fleshy leaves (pl. 2). 

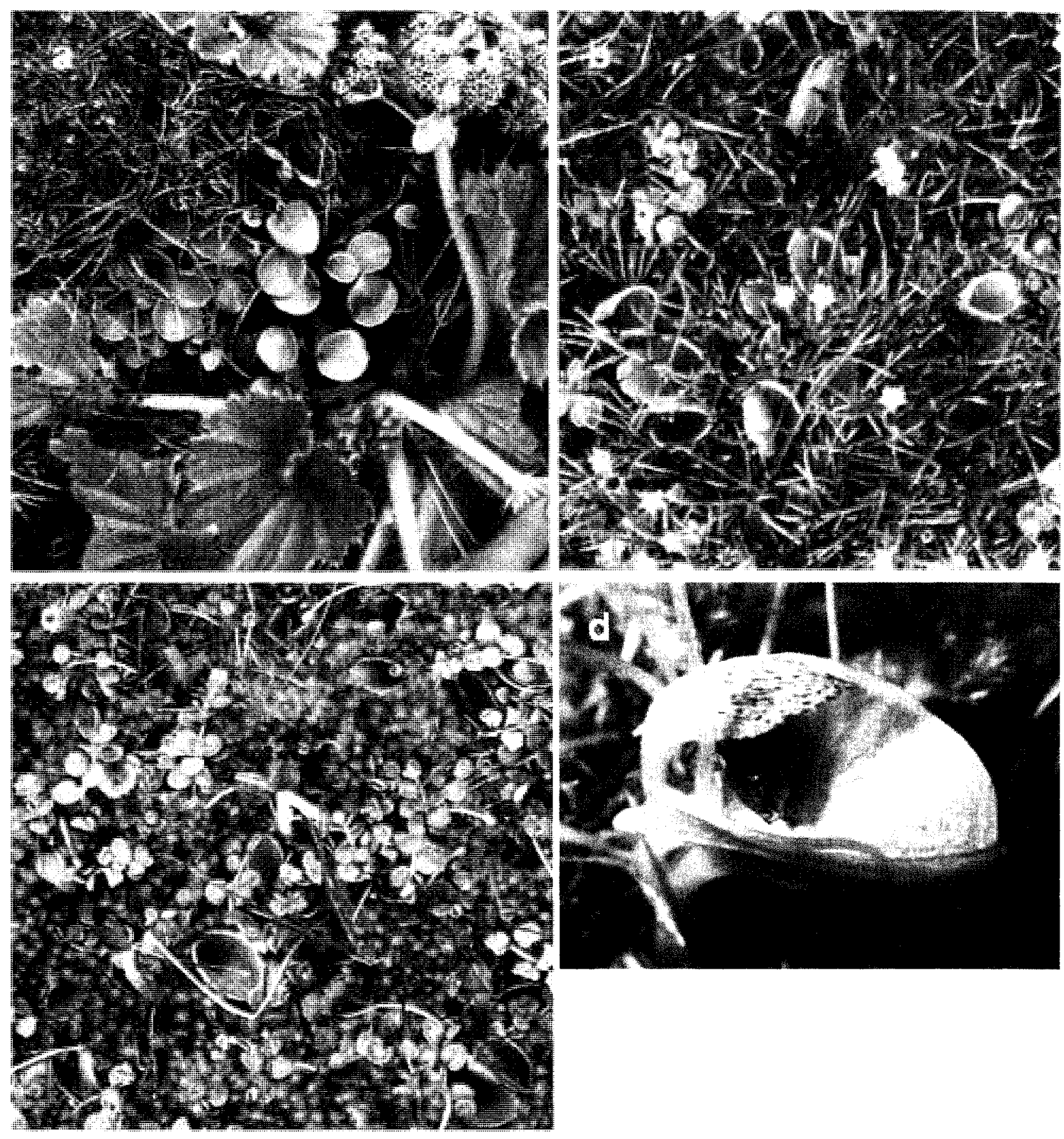

PLATE 1

Nematoceras dienemum leaves, flowers and habitat. a. leaves at Handspike, sheltered by Stilbocarpa in 2004. Orchid leaves are approximately 1.5-2 cm in length; b. Leaves at Handspike, in the absence of Stilbocarpa protection, in 2007; c. mature seed capsules at Bauer Bay. Orchid leaves are approximately $1.5 \mathrm{~cm}$ in length; seed capsules extend $5 \mathrm{~cm}$ above surface vegetation; $d$. flower at Handspike; leaf is approximately $1.7 \mathrm{~cm}$ in length. 


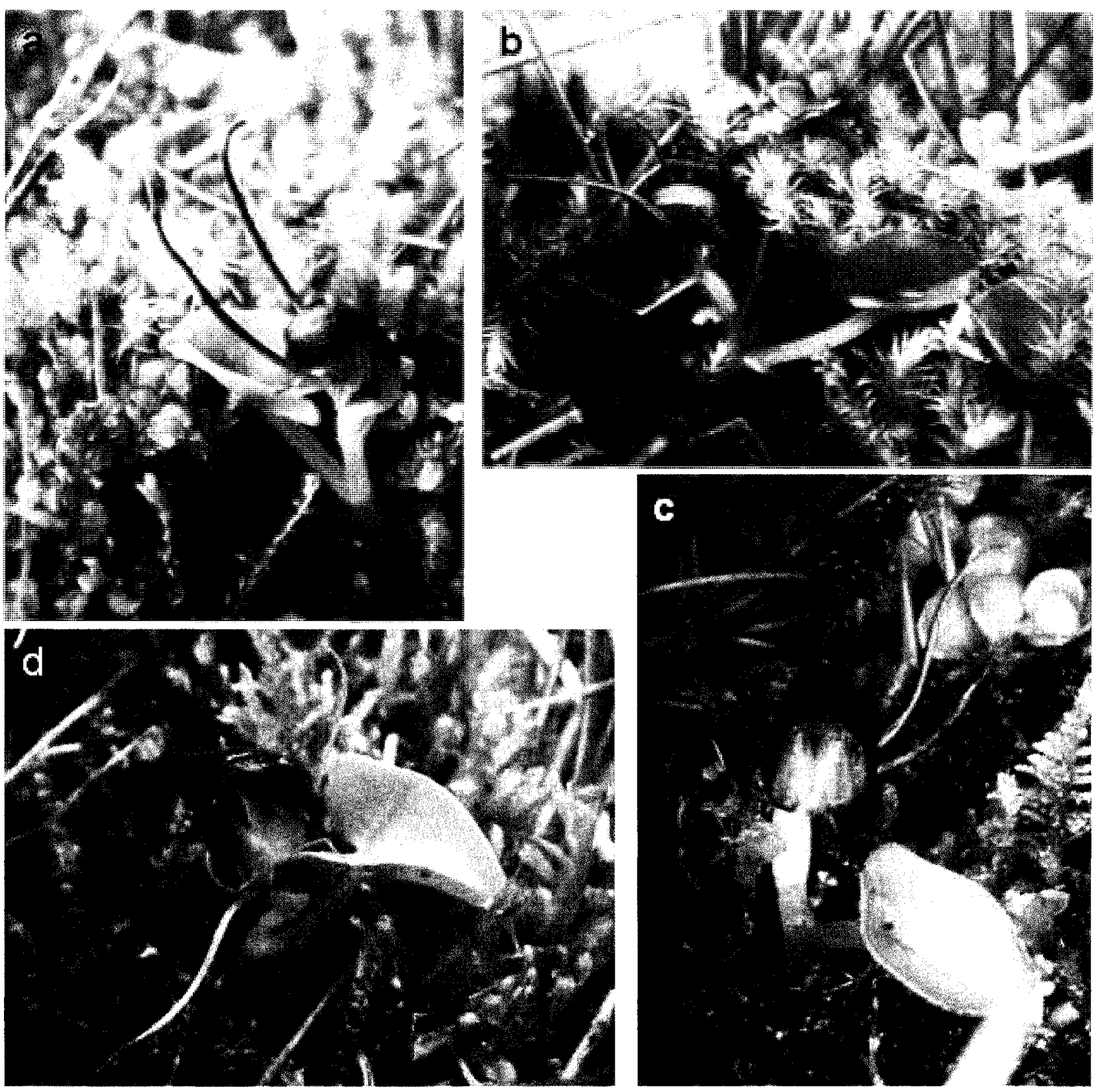

PLATE 2

Nematoceras sulcatum leaves, flower and habitat. a. flower in the Sawyer Creek valley; leaf is approximately $1.7 \mathrm{~cm} \mathrm{in} \mathrm{length;} b$. leaves and flower in the Green Gorge North basin; leaf is approximately $1.8 \mathrm{~cm}$ in length; c. flower in the Green Gorge North basin; leaf is approximately $1.8 \mathrm{~cm}$ in length; $d$. flowering plant from Red River; leaf is approximately $1.8 \mathrm{~cm}$ in length. 




PLATE 3

A single plant of Nematoceras dienemum from Bauer Bay, observed daily, and showing progression of the flower from bud to mature seed capsule without the flower ever opening. a. Flower buds emerging; late September; b. flowers remained as buds for several weeks, never opening or extending; late October; c. immature capsule (foreground), and shrivelled failed flower (background); late November; $d$. maturing and extending capsule; mid-December; e. mature capsule; late December; f. split capsule shedding seeds (visible on leaf); late December. Leaf is approximately $1.7 \mathrm{~cm}$ in length; capsule is $1.2 \mathrm{~cm}$ in length on a $2.7 \mathrm{~cm}$ stalk. 


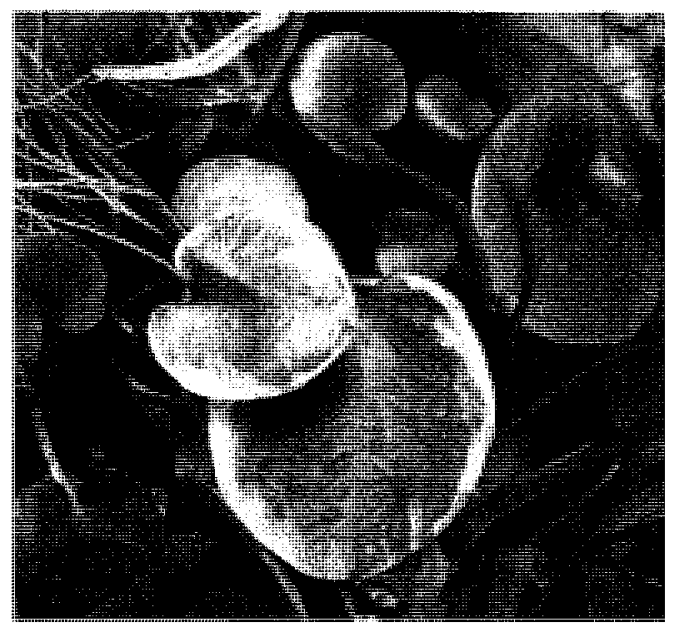

PLATE 4

Leaves of Nematoceras dienemum at Bauer Bay showing white mosaic symptoms, possibly indicating infection with a plant virus. Affected leaves are approximately $1.2-2.3 \mathrm{~cm}$ in length.

\section{Additional population}

At the southern end of Green Gorge mire, west of the outflow of Sawyer Creek into the mire, at about $20 \mathrm{~m}$ a.s.l. (only marginally higher than the population within the mire), a population of orchids has been reported (called Southwest Green Gorge in table 1; site 18 on fig. 1) which it was not possible to reach in summer 2004, during 2006-07 or in summer 2008-09. It is not known whether this is a population of $N$. dienemum, dispersed (perhaps by birds or wind) from the extensive population further north in the Green Gorge mire, or whether it is an additional population of $N$. sulcatum, dispersed downstream by water, wind or birds from populations further up the Sawyer Creek valley. This site is impossible to reach on foot unless the season is unusually dry, and we have not been able to access it in the past few years to confirm the species.

\section{Habitats}

Our field studies (berween 1977 and 2009; table 1) confirm the different habitats described for the two Macquarie Island orchid species (Clements et al. 2007). Nematocerds dienemum is known from sites along the west coastal terraces, berween Handspike Corner and Aurora Cave, from the Bauer Bay basin, and from the Green Gorge mire. All sites are less than $30 \mathrm{~m}$ above sea level, with bryophyte-dominated quaking mire or herb- and moss-dominated mire vegetation.

Several of the more accessible populations of Nematoceras have been monitored on an opportunistic basis over the past 20 years, including those at Bauer Bay, Handspike Corner and Sawyer Creek valley. Reports that these orchid colonies can "move" is probably due to the fact that just a few (if any) leaves are visible above ground at certain times of year (Nematoceras spp are not "winter green" sensu Sørensen 1941), but also in part to major site disturbance. For example, we have observed that a dense but small sub-population in a $3 \mathrm{~m} \times 2 \mathrm{~m}$ site at Bauer Bay which was thriving in early 2004 (with at least 100 seed capsules), in early 2006 was a deep muddy wallow made by the Southern Elephant Seal, Mirounga leonina (Linnaeus, 1758), and devoid of surface vegetation. Late in 2006, when disrurbance by elephant seals had diminished, a few apparently healthy orchid tubers were observed under bryophyte cover near the seal wallow. In early January 2007 , with the wallow no longer in use, a few leaves appeared at its edge, and in late January, orchids were in flower one metre from the wallow. The orchids had not been destroyed by the disturbance but had simply been pushed aside with the loose mire vegetation in the waterlogged soil.

In contrast, $N$. sulcatum populations apparently occur in at least four separate sites on the plateau uplands at 80-150 $m$ a.s.l., in seepage areas along the eastern side of the Sawyer Creek valley, beside drainage lines in the Green Gorge North basin, and in the Red River basin near drainage lines leading into a small lake and Red River. At all four sites the water table is close to the surface, with drainage towards Red River tributaries, Green Gorge mire and Sawyer Creek. The vegetation is short herb vegetation dominated by Festuca contracta Kirk, Agrostis magellanica Lam. and Luzula crinita Hook.f., with a mixture of bryophytes.

\section{Life histories}

Macquarie Island orchids generally appear above ground only in spring and summer between September and early April, with flowering generally occurring between November and January. Leaves have occasionally been observed as early as the end of August, but only within the bryophyte vegetation and not unfurled. In most years, many leaves appear during October. Flowering has only been reported between November and January, with immature and ripe seed capsules being observed in $N$. dienermum populations between January and March. Dying leaves have also been observed as late as April for both species.

\section{Flower development in $N$. dienemum}

We have followed the daily progression of two single flowers of an $N$. dienemum Bauer Bay plant over three months from September (pl. 3). Neither flower progressed from the bud stage, and one shrivelled and died within a few weeks. However, we observed that although the second flower bud also never opened, a seed capsule formed and ripened with shedding of many seeds ( $\mathrm{pl}$. $3 \mathrm{f}$ ), though viability was not tested.

\section{Seasonal variability in $N$. dienemum}

Most of our visual observations of orchid populations have been made on an opportunistic basis. Berween January and March 2004 numerous seed capsules were observed in orchid populations at Bauer Bay (pl. 1c), Handspike Corner and Green Gorge mire. Between late November 2006 and February 2007, many of the orchid populations flowered on Macquarie Island, including those at Green Gorge, Handspike Corner (pl. 1d) and Bauer Bay (fig. 1). However, it appeared that many of the flowers failed to open, or failed to set seed, and only around 10\% of the flowers were observed to form capsules. No orchids were observed with flowers or seed capsules on Macquarie Island in the 2007/2008 summer at Bauer Bay, or elsewhere. In late March 2009, one ripe seed capsule was observed at Gentoo Flats, more than 50 were seen at Bauer Bay (some shedding seeds, some unripe and just starting to elongate) and many unripe capsules were observed at Green Gorge mire. 


\section{Seasonal variability in $N$. sulcatum}

Between January and March 2004 neither flowers nor capsules were observed in the Sawyer Creek valley or Pyramid Peak populations. However, in the sumner of 2006-07 the populations near Pyramid Peak, Sawyer Creek valley (pl. 2a), Green Gorge North (pl. 2b, c) and Red River (pl. 2d) all flowered.

More detailed observations during 2006 showed that by early November, buds and flowers were appearing in most populations. By mid- to late November, some $30 \%$ of plants in the Pyramid Creek, Sawyer Creek valley and Green Gorge North populations were flowering, and the Red River population had flower buds. In mid-January the Red River population was still flowering. Unfortunately, it was not possible to visit flowering populations later in that season to observe whether seed capsule formation had occurred.

No flowers were seen in any populations in summer 2007-08. In December 2008 a few plants flowered at Pyramid Peak, but no capsules were seen in any of the $N$. sulcatum populations in March 2009.

\section{Leaf mosaic symptoms}

At both Bauer Bay and Handspike Corner, a few leaves of $N$. dienemum have been observed with a striking white mosaic, similar to symptoms of viral disease (pl. 4). At one site at Bauer Bay, such leaves have been noted in three separate years at the same location. Whether these orchids are infected with a plant virus, or have a genetic alteration leading to mosaic symptoms remains to be analysed, but any virus is likely to be unrelated to the only plant virus reported from Macquarie Island, Stilbocarpa mosaic bacilliform virus, SMBV (Skotnicki et al. 2003). Similar white mosaic markings have also been observed on leaves of Cardamine corymbosa Hook.f. at two locations on the island in three separate years: these also have yet to be analysed for cause of the symptoms.

\section{DISCUSSION}

\section{Populations and habitats}

Eleven populations confirmed as $N$. dienemum are now known on Macquarie Island. The largest population is at Handspike Corner with perhaps 5000 plants; nine smaller populations are known from locations further south along the western coastal terrace, and one extensive population is known from the eastern coast in the mire at Green Gorge (fig. 1, table 1). In addition, a further four orchid populations have been observed along the western coastal terrace, and it seems most likely these will also be $N$. dienemum. Our observations confirm two previously described populations of $N$. sulcatum, and have located two additional populations believed to be $N$. sulcatum. The two populations in Sawyer Creek valley (fig.1, table 1), are found, as Clements et al. (2007) describe, amongst moist short herb vegetation dominated by graminoids and bryophytes. The populations in the Green Gorge North Basin and Red River valley are in similar vegetation with the water table close to the surface along a drainage line. All are between $80 \mathrm{~m}$ and $100 \mathrm{~m}$ a.s.l.

\section{Life histories}

The leaves of Nematoceras dienemum and N. sulcatum die back annually, and new leaf growth appears in spring. During the winter, $N$. dienemum plants are protected by the bryophytes and other mire plants, and $N$. sulcatum by the graminoid plants amongst which they grow. They have storage tissue in roots and tubers via which vegetative reproduction occurs. They fit the usual pattern of hemicryptophyte plants (Raunkiaer 1934) which are commonly herbaceous perennials found in cold moist climates.

\section{Reproduction in Nematoceras}

Nematoceras orchids reproduce vegetatively by production of daughter tubers on stolons, and sexually by forming seeds following pollination (Clements et al. 2007).

The estimates of population sizes in table 1 are based on the number of leaves above ground in summer, since each Nematoceras plant has only a solitary leaf above ground (Clements \& Jones 2007). However, because the species can grow vegetatively from tubers, clumps (or colonies) of plants will be clonal. It is not possible to say how many genetically distinct individuals are represented in the population, but it is likely to be considerably fewer than the number of leaves. Flowers have been observed at some locations in some years, but the number of flowers is vastly smaller than the number of leaves in any area. It is not possible to say from our observations what proportion of the plants (leaves) that have been observed represent reproductively mature individuals capable of flowering and setting seed. Both the floral morphology of $N$. dienemum and the friable nature of the pollen (Clements \& Jones 2007) are consistent with the possibility of autogamy (self-pollination), a feature of life histories of plants in isolated or extreme environments. The numerous maturing seed capsules observed in the field in summer 2004 were taken as an indication of autogamy, but alternatively could indicate presence of an active pollinator (Clements et al. 2007). Although our daily observations of flower development over three months ( $\mathrm{pl} .3$ ) were made on only two flowers, they confirm that autogamy, specifically cleistogamy (self-pollination in unopened flowers), can occur in $N$. dienemum.

We have no observations concerning the mode of pollination in $N$. sulcatum. No $N$. sulcatum seed capsules have yet been seen (perhaps because no observer has been in the right place at the right time, or perhaps because they are not formed), although the flower structure of this orchid appears consistent with insect pollination. The timing of flower and capsule development of both $N$. dienemum and $N$. sulcatum is comparable to the reproductive behaviour of the large herbs Stilbocarpa polaris and Pleurophyllum hookeri Buchan. on Macquarie Island: perennials with slow to very slow phenology, and extensive storage tissues (Bergstrom et al. 1997). Although nothing is known of their rate of seed germinability, the orchids can, like $S$. polaris and $P$. hookeri, be regarded as perennial stayers (sensu During 1979 , Bergstrom et al. 1997).

It is clear that there is considerable variability in the extent of flowering from year to year. The summers of 2003-04 and 2006-07 were "good" flowering seasons for N. dienemum; 2007-08 was a "poor" one. For N. sulcatum, summer 2006-07 was a good flowering season; 2003-04 and 2007-08 were poor ones. At this stage we do not know the determinant for good or bad flowering seasons in 
these orchids. Similarly, the megaherb daisy, Pleurophyllum hookeri, does not flower annually on Macquarie Island, and the determinant for flower initiation is not known.

Although temperatures on the island are low and windspeeds are high, moisture for plant growth is available all year (Pendlebury \& Barnes-Keoghan 2007). Plant productivity, as measured in closed vegetation dominated by Poa foliosa (Hook.f.)Hook.f., Stilbocarpa polaris and Pleurophyllum hookeri, is high (Jenkin \& Ashton 1970 , Jenkin 1975, Hnatiuk 1978). Nevertheless, for S. polaris and $P$ hookeri, despite their high biomass production, completing the sequence from flower initiation to seed and fruit maturity appears to take longer than one season, implying the presence of pre-formed flower buds that overwinter (Bergstrom et al. 1997). Similarly, for $N$. sulcatum where buds and flowers were observed in early November, only a few weeks after leaves appeared, it is likely that pre-formation of flower buds is involved; this seems likely also for $N$. dienemum. For plants with overwintering flower buds, environmental conditions in the one or two summers preceding flowering influence flower bud initiation (Mark 1970, Billings 1974). In addition, it may be that flowering and setting seed at two- or three-year intervals is more metabolically sustainable than annually.

\section{Origin and dispersal of Macquarie Island orchids}

Two separate long-distance over-ocean dispersals by wind or birds from New Zealand seem the most likely means by which ancestors of the two endemic species of Nematoceras reached Macquarie Island followed by on-island evolution and dispersal (Clements et al. 2007). Although long-distance dispersal (LDD) events over distances of greater than 250 $\mathrm{km}$ are hypothesised to occur only once in more than one million years under the mean trend, they may occur far more frequently as a result of processes or events that "break the rules". Such "non-standard" mechanisms include extreme climatic events, prolonged turbulent updrafts and cyclonic activity (Nathan 2008), phenomena that are certainly part of sub-Antarctic weather patterns (Streten 1988). Genetic studies of plants from Svalbard and surrounding Arctic regions have shown the source populations for post-glacial, Holocene plant colonisation of Svalbard ranged from Greenland to northwestern Russia. Probable vectors include wind. Dispersal mechanisms of the early to mid-Holocene are likely still to be operating today, and LDD can be assumed still to occur with regularity in Arctic and other regions (Alsos et al. 2007).

Humans are unlikely to have played a role in the introduction of orchids to Macquarie Island, because populations of $N$. dienemum tend to be found distant from the main centres of habitation on the island, in very wet and boggy "featherbed" areas which are difficult to cross on foot and therefore usually avoided (Brown et al. 1978). For the same reasons humans are unlikely to have been agents of dispersal for $N$. dienemum around the island.

Similarly, humans are unlikely to have dispersed $N$. sulcatum around Macquarie Island. Although three of the known populations occur very near the sole Overland walking track which runs down the length of the island, they are located well away from parts of the island most frequently visited, high on the plateau and some distance from the coast. The orchid populations in the Green Gorge North Basin, which occur in similar vegetation to the Sawyer Creek populations, are far away from any walking track in very wet ground difficult to cross. We were unable to reach these populations in 2007 due to the high level of the water table that season.

Bergstrom et al. (2006) argue that, for Poa litorosa Cheeseman and Carex trifida Cav., two species found elsewhere but with restricted distributions on Macquarie Island, the largest populations at Handspike Point constitute the founder populations. Similarly, it could be suggested that the extensive population of $N$. dienemum at nearby Handspike Corner is the founder population for this species, in the sense that this is a likely site for first arrival of the ancestral propagule(s) from which $N$. dienemum developed, and subsequently dispersed to its other sites around the island.

For $N$. dienemum, dispersal around the island could be either by seed, windblown from the capsules which are held erect on a thickened peduncle $4-8 \mathrm{~cm}$ long (Clements $\&$ Jones 2007), or via dispersal of their globose to ellipsoid vegetative tubers, $1-5 \mathrm{~mm}$ in diameter. $N$. sulcatum similarly has globose to ellipsoid tubers, $1-7 \mathrm{~mm}$ long by $1-6 \mathrm{~mm}$ wide. For seeds to germinate, they would need to encounter the appropriate fungus with which to establish a mycorrhizal association. The identity of the fungus is not yet known for either species, but it is likely to be widespread in Macquarie Island mires and moist short herb vegetation.

For normally subterranean tubers to be dispersed away from the original clump of orchids, they would need to be detached and brought to the surface. Such disturbance of orchid plants has been noted and presumed to be by birds, probably Weka, Gallirallus australis scotti (Ogilvy-Grant, 1905) or Kelp Gulls, Larus dominicanus Lichenstein, 1823, seeking to eat the tubers and fleshy roots (Brown et al. 1978, Copson 1984). Weka, introduced from Stewart Island in 1867 (Cumpston 1968), were eradicated from Macquarie Island in 1988 (Copson 1995, Copson \& Whinam 2001). They were on the island for a little over 100 years, replacing the ecologically very similar Macquarie Island subspecies of the Pacific Banded Rail, Rallus philippensis macquariensis Hutton, 1879, which became extinct in the late nineteenth century. Although usually described as flightless, at Macquarie Island it was a capable though reluctant flier. Given appropriate atmospheric conditions, it could well have flown or been blown from one mire site to another on the island, very possibly with seeds or tubers stuck in mud on feet or feathers.

Other birds, indigenous to the island, also scrabble amongst mire and moist closed short vegetation, presumably seeking terrestrial invertebrates as food: for example Dominican (Kelp) Gulls (Selkirk et al. 1990, Parks and Wildlife 2006) and ducks (Black Duck, Anas superciliosa Gmelin, 1789, Mallard Anas platyrhynchnos Linnaus, 1758). Dominican (Kelp) Gulls are known to congregate on the flats below and to the north of Pyramid Peak, at the head of the Sawyer Creek valley. Brown Skuas, Catharacta lonnbergi Mathews, 1912, have been observed turning over moss polsrers in feldmark, presumably foraging for invertebrates such as worms and slugs (Selkirk et al. 1990). Skuas congregate adjacent to some lakes on the island where they bathe and groom themselves; the surrounding moist closed short herb vegetation can become quite disturbed by the amount of skua traffic across it. We have observed disturbance of a $N$. dienemum site near. Bauer Bay hut by wallowing elephant seals, as described above. Once dislodged, tubers could be moved to new sites on the island over short distances by wind, and over longer distances entangled on birds. 
In an investigation of floral phenology in the South Georgia vascular flora, Walton (1982) found many of the adaptations to cold summer climates described by Billings (1974) for plants of high latitude and alpine regions. Both species of Nematoceras similarly exhibit life history strategies well suited to life in the sub-Antarctic environment:

- they are perennial

- they are capable of vegetative reproduction from tubers

- although not winter-green (sensu Sørensen 1941) they have storage roots and tubers from which spring vegetative growth can be supplied

- their tubers and overwintering meristems are well protected, just below the surface of surrounding bryophyte and graminoid vegetation

- we infer that flower buds are pre-formed in the season preceding flowering

- $N$. dienemum can be autogamous and cleistogamous, though may also be capable of insect pollination. Such information is not known for $N$. sulcatum.

Although $N$. dienemum and $N$. sulcatum live and reproduce successfully in the isolated, sub-Antarctic environment, these species are considered vulnerable ( $N$. dienemum) and endangered ( $N$. sulcatum) species under the Tasmanian Threatened Species Act of 1995 as their numbers are low and they are confined to the northern half of Macquarie Island. Looking back, the presumed on-island evolution from two separate arrivals of two separate ancestors makes these two endemic orchid species fascinating. Looking forward, they will continue to be fascinating as we learn more about their biology, and as we observe the way in which the populations and the species respond to environmental change, particularly the temperature increase and variation in available moisture (Pendlebury \& Barnes-Keoghan 2007) that is occurring in the sub-Antarctic.

\section{ACKNOWLEDGEMENTS}

This work was supported by an Australian Antarctic Science Grant. We thank the Australian Antarctic Division for logistical support, the Tasmanian Parks and Wildlife Service for access to Macquarie Island, and Tasmanian Nature Conservation for permission to collect plant specimens on Macquarie Island. We thank J. Whinam, P. McBride, T. Rudman, N. Carmichael, P. Bricher, J. Wasley and others resident on Macquarie Island for assistance with field collections and observations over the years.

\section{REFERENCES}

Adamson, D.A., Selkirk, P.M., Price, D.M., Ward, N. \& Selkirk, J.M. 1996: Pleistocene uplift and palaeoenvironments of Macquarie Island: evidence from palaeobeaches and sedimentary deposits. Papers and Proceedings of the Royal Society of Tasmania 130: 25-32.

Alsos, I.G., Eidesen, P.B., Ehrich, D., Skrede, I., Westergaard, K., Jocobsen, G.H., Landvik, J.L., Taberlet, P. \& Brochmann, C. 2007: Frequent long-distance plant colonisation in the changing Arctic. Science 316: 1606-1609.

Bergstrom, D.M. \& Selkirk, P.M. 1987: Reproduction and dispersal of mosses on Macquarie Island. Symposia Biologica Hungarica 35: 247-257.

Bergstrom, D.M., Selkirk, P.M., Keenan, H.M. \& Wilson, M.E. 1997: Reproductive behaviour of ten flowering plant species on subantarctic Macquarie Island. Opera Botanica 132:109-120.

Bergstrom, D.M., Turner, P.A.M., Scott, J., Copson, G. \& Shaw, J. 2006: Restricted plant species on sub-Antarctic Macquarie and Heard Islands. Polar Biology 29: 532-539.

Billings, W.D. 1974: Arctic and alpine vegetation: plant adaptations to cold summer climates. In Ives, J.D. \& Barry, R.G. (eds): Arctic and Alpine Environments. Methuen, London: 403-443.

Brown, M.J., Jenkin, J.F., Brothers, N.P. \& Copson, G.R. 1978: Corybas macranthus (Hook.f.) Reichb.f. (Orchidaceae), a new record for Macquarie Island. New Zealand Journal of Botany 16: 405-407.

Clements, M.A. \& Jones, D.L. 2006: A new species of Nematoceras and characterization of $N$. dienemum (Orchidaceae), both from subantarctic Macquarie Island. Teloped 11(4): 405-411.

Clements, M.A., Mackenzie, A.M., Copson, G.R., Molloy, B.P.J., Carmichael, N., Skotnicki, M.L. \& Selkirk, P.M. 2007: Biology and molecular phylogenetics of Nematoceras sulcatum, a second endemic orchid species from subantarctic Macquarie Island. Polar Biology 30: 859-869.

Copson, G.R. 1984: An annotated atlas of the vascular flora of Macquarie Island. ANARE Research Notes 18: 1-70.

Copson, G.R. 1995: An integrated pest strategy for subantarctic Macquarie Island. In Proceedings of the 10th Vertebrate Pest Control Conference, Hobart, May 1995.

Copson, G.R. \& Whinam, J. 2001: Review of ecological restoration programme on subantarctic Macquarie Island: Pest management progress and future directions. Ecological Management ir Restoration 2(2): 129-138.

Cumpston, J.S. 1968: Macquarie Island. ANARE Scientific Reports, Series A (1), Narrative. Antarctic Division, Department of External Affairs, Melbourne: 380 pp.

Dartnall, H.J.G., Hollwedel, W. \& de Paggi, J.C. 2005: The freshwater fauna of Macquarie Island, including a redescription of the endemic water- flea Daphnia gelida (Brady) (Anomopoda: Crustacea). Polar Biology 28: 922-939.

During, H.J. 1979: Life strategies of bryophytes: a preliminary review. Lindbergia 7 : 113-125.

Hnatiuk, R.J. 1978: The growth of tussock grasses on an equatorial high mountain and on two sub-Antarctic islands. In Troll, C. \& Lauer, W. (eds): Geoecological Relations Between the Southern Temperate Zone and the Tropical Mountains: 159-190.

Jenkin, J. 1975: Macquarie Island, Subantarctic. In Rosswall, T. \& Heal, O.W. (eds): Structure and Function of Tundra Ecosystems. Ecological Bulletins, Stockholm, 20: 375-397.

Jenkin, J. \& Ashton, D.H. 1970: Productivity studies on Macquarie Island vegetation. In Holdgate, M.W. (ed.): Antarctic Ecology 2: 851-863.

Jones, D.L. 1993: Corybas dienemus D.L. Jones sp.nov. Flora Australia 50: 572 .

Mackenzie, A., Carmichael, N., Clements, M., Copson, G., Selkirk, P. \& Skotnicki, M. 2005: Australia’s Subantarctic Orchids. In Raynal-Roques, A., Roguenant, A. \& Prat, D. (eds): Proceedings of the 18th World Orchid Conference, Dijon France. Naturalia, France: 321-324.

Mark, A.F. 1970: Floral initiation and development in New Zealand alpine plants. New Zealand Journal of Botany 8: 67-75.

Moore, D.M. 1983: Flora of Tierra del Fuego. Missouri Botanical Garden, St Louis: 396 pp.

Muñoz, J., Felicisimo, A.M., Cabezas, F., Burgaz, A.R. \& Martínez, I. 2004: Wind as a long-distance dispersal vehicle in the Southern Hemisphere. Science 304: $1144-1147$.

Nathan, R. 2008. Long-distance dispersal of plants. Science 313: 786-788, with correction http://www.sciencemag.org/cgi/ content/full/sci;322/5900/375 (accessed 2 April 2009). 
NZ Native Orchid Group 2009. Species By Region. http://www. nativeorchids.co.nz/Orchid_Districts.html (accessed 29 October 2009).

Parks and Wildlife Service 2006: Macquarie Island Nature Reserve and World Heritage Area Management Plan 2006. Parks and Wildife Service, Department of Tourism, Arrs and the Environment, Hobart: $175 \mathrm{pp}$.

Pendlebury, S.F., \& Barnes-Keoghan, I.P. 2007: Climate and climate change in the sub-Antarctic. Papers and Proceedings of the Royal Society of Tasmania 141(1): 67-82.

Raunkaier, C. 1934: The Life Forms of Plants and Statistical Plant Geography. Oxford University Press, Oxford: $632 \mathrm{pp}$.

Selkirk, P.M., Seppelt, R.D. \& Selkirk, D.R. 1990: Subantartic Macquarie Island: Environment and Biology. Cambridge University Press, Cambridge: 285 pp.

Skotnicki, M.L., Selkirk, P.M., Kitajima, E., McBride, T.P., Shaw, J. \& Mackenzie, A. 2003: The first subantarctic plant virus report: Stilbocarpa mosaic bacilliform badnavirus (SMBV) from Macquarie Island. Polar Biology 26: $1-7$.
Sørensen, T. 1941: Temperature relations and phenology of the north-east Greenland flowering plants. Meddelelser om Gronland 125 (9): 1-305.

Streten, N.A. 1988: The climate of Macquarie Island and its role in atmospheric monitoring. Papers and Proceedings of the Royal Society of Tasmania 122(1): 91-106.

Walton, D.W.H. 1982: Floral phenology in the South Georgian vascular flora. British Antarctic Survey Bulletin No 55 : $11-25$.

Wapstra, H., Wapstra, A., Wapstra, M. \& Gilfedder, L. 2005. Little Book of Common Names for Tasmanian Plants. Department of Primary Industries, Water and Environment. Hobart, Tasmania: 88 pp.

Wapstra, H., Wapstra, A., Wapstra, M. \& Gilfedder, L. 2007. Addendum to Little Book of Common Names for Tasmanian Plants. http://www.dpiw.tas.gov.au/inter.nsf/ Attachments/LJEM-78K3D6/\$FILE/Addendum\%20 2007.pdf (accessed 4 February 2009).

(accepted 3 November 2009) 